\title{
Oxidative Stress and Down Syndrome. Do Antioxidants Play a Role in Therapy?
}

\author{
J. MUCHOVÁ ${ }^{1}$, I. ŽITŇANOVÁ ${ }^{1}$, Z. ĎURAČKOVÁ ${ }^{1}$ \\ ${ }^{1}$ Institute of Medical Chemistry, Biochemistry and Clinical Biochemistry, Medical Faculty, \\ Comenius University, Bratislava, Slovakia
}

Received December 16, 2013

Accepted March 31, 2014

On-line June 5, 2014

\section{Summary}

Oxidative stress is a phenomenon associated with imbalance between production of free radicals and reactive metabolites (e.g. superoxide and hydrogen peroxide) and the antioxidant defences. Oxidative stress in individuals with Down syndrome (DS) has been associated with trisomy of the $21^{\text {st }}$ chromosome resulting in DS phenotype as well as with various morphological abnormalities, immune disorders, intellectual disability, premature aging and other biochemical abnormalities. Trisomy 21 in patients with DS results in increased activity of an important antioxidant enzyme $\mathrm{Cu} / \mathrm{Zn}$ superoxide dismutase (SOD) which gene is located on the $21^{\text {st }}$ chromosome along with other proteins such as transcription factor Ets-2, stress inducing factors (DSCR1) and precursor of beta-amyloid protein responsible for the formation of amyloid plaques in Alzheimer disease. Mentioned proteins are involved in the management of mitochondrial function, thereby promoting mitochondrial theory of aging also in people with DS. In defence against toxic effects of free radicals and their metabolites organism has built antioxidant defence systems. Their lack and reduced function increases oxidative stress resulting in disruption of the structure of important biomolecules, such as proteins, lipids and nucleic acids. This leads to their dysfunctions affecting pathophysiology of organs and the whole organism. This paper examines the impact of antioxidant interventions as well as positive effect of physical exercise on cognitive and learning disabilities of individuals with DS. Potential terapeutic targets on the molecular level (oxidative stress markers, gene for DYRK1A, neutrophic factor BDNF) after intervention of natural polyphenols are also discussed.

\section{Key words}

Down syndrome - Cognitive functions - Oxidative stress • Antioxidants • Physical activities • Polyphenols

\section{Corresponding author}

Z. Ďuračková, Institute of Medical Chemistry, Biochemistry and Clinical Biochemistry, Faculty of Medicine, Comenius University, Sasinkova 2, 81372 Bratislava, Slovakia. E-mail: zdenka.durackova@fmed.uniba.sk

Down syndrome (DS) is a genetic disorder associated with trisomy 21. Although pathological mechanisms leading to DS phenotypes are not known yet, it is obvious that the presence of the third chromosome 21 is responsible for altered development during embryogenesis and organogenesis (Šustrová et al. 2004). It is still unclear how the additional chromosome 21 interferes with normal developmental processes and which structural changes are formed in fetus.

Oxidative stress is a phenomenon that is often discussed in connection with many diseases, such as atherosclerosis and cardiovascular diseases, neurodegenerative diseases, rheumatoid arthritis, diabetes mellitus, cancer and mental disorders. Oxidative stress is also considered as one of the main causes of aging. Oxidative stress is defined as an imbalance between production of free oxygen and nitrogen radicals (FR) and their reactive metabolites (RM) on the one hand, and on the other hand, by the ability of the organism to eliminate toxic action of these FR and their RM. This imbalance in favor of the RM leads to the oxidative modification of 
important biomolecules such as lipids, proteins and nucleic acids, resulting in the damage or change of the function of several organs or the whole organism. Free radicals including superoxide anion radical (abbreviated as superoxide $\mathrm{O}_{2}{ }^{-}$), trigger formation of a number of new FR or RM such as the most toxic hydroxyl radical ( $\mathrm{OH})$, singlet oxygen $\left({ }^{1} \mathrm{O}_{2}\right)$, and hydrogen peroxide $\left(\mathrm{H}_{2} \mathrm{O}_{2}\right)$ (Fig. 1).

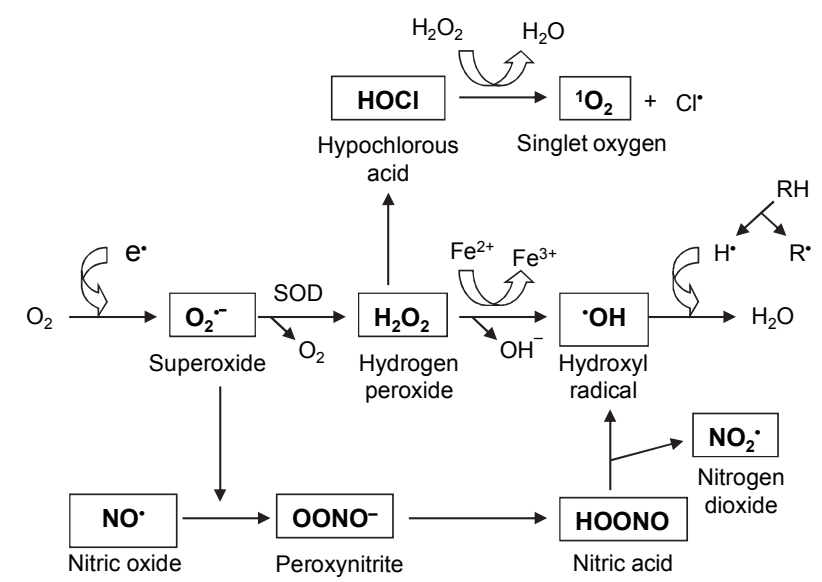

Fig. 1. Mutual conversion of free radicals and their metabolites.

Initially, the FR and RM were assumed to have only negative functions in the organism. However, now it is known that some of them play an important role in certain physiological processes, e.g. $\mathrm{O}_{2}^{-{ }^{-}}$and $\mathrm{H}_{2} \mathrm{O}_{2}$ are part of the myeloperoxidase microbicidal system of phagocytic cells during phagocytosis. In addition, FR and $\mathrm{RM}$ are involved in several oxidation, hydroxylation and carboxylation reactions during detoxification of the organism, in peroxidase reactions during fertilization of eggs by sperms or in prostaglandin reactions. It is currently accepted that under certain circumstances FR and RM as well as a weak or moderate oxidative stress play an important regulatory role in transduction of information within cells (signaling pathways) and between cells, which affects several biological functions such as apoptosis (cell death), proliferation, differentiation (realization of genetic information), repair systems (repair of damaged molecules) and other processes (Ďuračková 2010).

However, FR and RM can become toxic during uncontrolled formation causing damage to lipids, cell membranes as well as lipoproteins in the periphery. They are also detrimental to proteins, they modify function of hormones and receptors and activity of enzymes. Oxidative damage to nucleic acids results in mutations of
DNA bases which might lead to initiation of cancer.

Against FR and RM toxicity organisms have built defence mechanisms operating on three levels:

a) systems preventing formation of FR and RM (e.g. allopurinol is an inhibitor of the enzyme xanthine oxidase catalyzing formation of superoxide and uric acid from xanthine and hypoxanthine);

b) antioxidants that scavenge and eliminate already formed FR and convert them into non-radical and non-toxic molecules;

c) if antioxidant protection fails and biomolecules (lipids, proteins and nucleic acids) are damaged, repair systems detect the damaged molecules and restore or degrade them (e.g. DNA with repair endonucleases, damaged lipids with lipases, damaged proteins with proteasomes).

Antioxidants from biological point of view are substances that at low concentrations can prevent oxidation of important biomolecules and thus eliminate toxic effects of FR and RM by generation of non-toxic products. In the organism there are present either high molecular weight antioxidants (enzymatic e.g. superoxide dismutase or non-enzymatic e.g. transferrin) or endogenous low molecular weight antioxidants (e.g, glutathione, uric acid). Exogenous antioxidants, e.g. vitamins $\mathrm{C}$ and $\mathrm{E}$ or natural flavonoids (e.g. catechin, quercetin) and polyphenols (e.g. resveratrol) (Table 1) also significantly contribute to the antioxidant defence of the organism.

The most important antioxidant enzymes include the enzyme superoxide dismutase (SOD), which occurs in the body in three isoforms: $\mathrm{Cu} / \mathrm{Zn} \mathrm{SOD}$ - intracellular dimeric enzyme containing $\mathrm{Cu}$ and $\mathrm{Zn}$ ions in the active centre (also labeled as SOD-1), extracellular $\mathrm{Cu} / \mathrm{Zn}$ SOD has the same ions in the active centre but different tetrameric apo-enzyme and mitochondrial also tetrameric Mn SOD (SOD-2) containing Mn ion in the active centre. SOD catalyzes dismutation of superoxide to non-radical molecules, oxygen and hydrogen peroxide. Paradox of this reaction is generation of the new harmful oxidant, hydrogen peroxide. Organism is, however, a wise system containing two other enzymes, glutathione peroxidase (GPx) and catalase (CAT), which can decompose hydrogen peroxide to oxygen and water (Fig. 2). Therefore it is very important to have the right ratio between activities of SOD and (GPx + CAT) together.

Although pathological mechanisms leading to DS phenotypes are not known yet, it is obvious that the presence of the third chromosome 21 is responsible for 
altered development during embryogenesis and organogenesis (Šustrová et al. 2004). How the additional chromosome 21 influences normal developmental processes in the fetus of trisomic individuals is still unknown.

Table 1. Overview of the most important antioxidants.

Endogenous and exogenous antioxidants

\begin{tabular}{ll}
\hline High molecular weight & Low molecular weight \\
\hline - Superoxide dismutase (SOD) & $\bullet$ Uric acid \\
- Glutathione peroxidase (GPx) & $\bullet$ Ascorbic acid (vitamin C) \\
- Catalase (CAT) & $\bullet$ Lipoic acid \\
- Albumin & $\bullet$ Glutathione (GSH) \\
- Transferrin & $\bullet$ Tocopherol (vitamin E) \\
& $\bullet$ Coenzyme Q (CoQ) \\
\hline
\end{tabular}

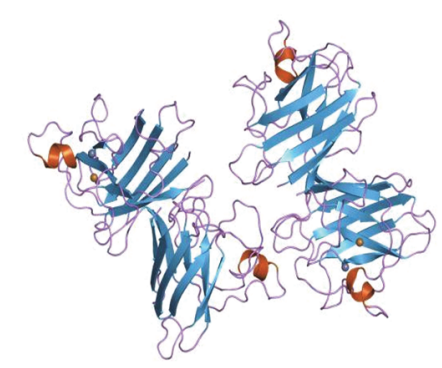

$C u / Z n S O D(S O D)$

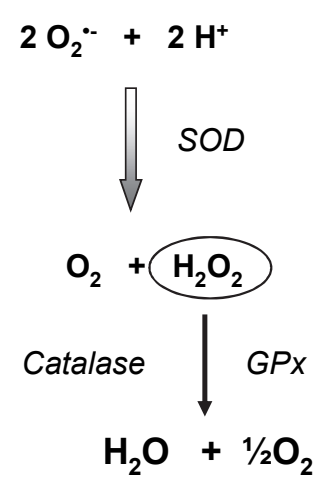

Fig. 2. $\mathrm{Cu} / \mathrm{Zn}$ superoxide dismutase $(\mathrm{SOD})$ function in the organism.

It has long been assumed that increased activity of the enzyme $\mathrm{Cu} / \mathrm{Zn}$ SOD contributes to the Down syndrome pathology. The gene for this enzyme is located on the distal part of the chromosome 21 (Tan et al. 1973). This gene has been used as a molecular marker for DS (Duračková 2004). Patients with DS have 150 \% activity of the enzyme $\mathrm{Cu} / \mathrm{Zn}$ SOD resulting in increased production of $\mathrm{H}_{2} \mathrm{O}_{2}$ as well as in an imbalance in the superoxide concentrations leading to disorders in microbicidal systems and immunity (Šustrová and Šaríková 1997). Slow degradation of hydrogen peroxide due to the low activity of catalase and not sufficiently increased GPx activity leads to disturbed ratio of $\mathrm{SOD} /(\mathrm{GPx}+\mathrm{CAT})$ (Muchová et al. 2001). These changes result in changed redox state of cells (Garaiová et al. 2004) and in modulation of signal transduction pathways affecting cell apoptosis (Monti et al. 1992), immune processes and activities of repair systems (Subba Rao 2007). Furthermore, increased expression and activity of SOD leads to an imbalance in the concentration of metal ions, especially $\mathrm{Cu}$ and $\mathrm{Zn}$. It was found that also antioxidant element selenium is at insufficient concentrations in DS individuals (Kadrabová et al. 1996, Meguid et al. 2001).

Increased oxidative stress in DS individuals has been confirmed in multiple studies. An increased concentration of uric acid and its non-physiological metabolite allantoin was found in individuals with DS (Žitňanová et al. 2004), as well as the marker of oxidative damage to proteins (protein carbonyls), but the marker of oxidative damage to lipids (4-hydroxynonenal) was unchanged (Žitňanová et al. 2006). Disorder in the level of reduced glutathione, an important redox marker, was found in individuals with DS, along with increased production of the marker of oxidative damage to lipids, malondialdehyde and marker of aging, lipofuscin in erythrocytes and serum of children with DS (Muchová et al. 2007).

Oxidative stress affects the number of processes in DS patients (Kedziora and Bartosz 1988). Especially it affects:

- Immunity - increased activity of $\mathrm{Cu} / \mathrm{Zn}$ SOD traps also superoxide necessary for the proper functioning of microbicidal systems and generates an increased concentration of $\mathrm{H}_{2} \mathrm{O}_{2}$ affecting mainly the immune response through modification of signaling pathways in activation of phagocytosis. Increased activity of $\mathrm{Cu} / \mathrm{Zn} \mathrm{SOD}$ is involved in impairment of neutrophil 
functions, mainly in the decrease of their bactericidal activity, which is the reason of increased tendency of DS individuals to bacterial infections (Šustrová 2007).

- It increases the risk of cancer - increased DNA damage was found in urine and reduced ability of the DNA repair in children with DS (Morawiec et al. 2008). Zana et al. (2006) unlike Morawiec found no difference in repair ability of DNA, probably because of the small number of subjects involved in the study (7 children and 18 adults). Presence of an additional chromosome may contribute to genomic instability, which might be the reason of higher sensitivity of DS patients to cancer disease, particularly leukemia.

- It affects mental development - people with DS were found to have a positive correlation between GPx activity and IQ and a negative correlation between GPx and the marker of lipid peroxidation as well as lipofuscin formation (Weiss 1984). On the other hand, disturbed ratio of SOD/GPx is associated with reduced ability to memorize (Strydom et al. 2009).

- Premature aging - for a long time it has been assumed that the increased production and activity of $\mathrm{Cu} / \mathrm{Zn}$ SOD is responsible for changing the redox potential of cells and pro-oxidation state of patients with DS as well as for many pathological features. Later on, several disorders in mitochondrial enzyme activities were found as well as the impairment of repair system of oxidatively damaged mitochondrial DNA. As individuals with DS show premature signs of aging, interest has turned to the study and review of mitochondrial theory of aging in relation to DS.

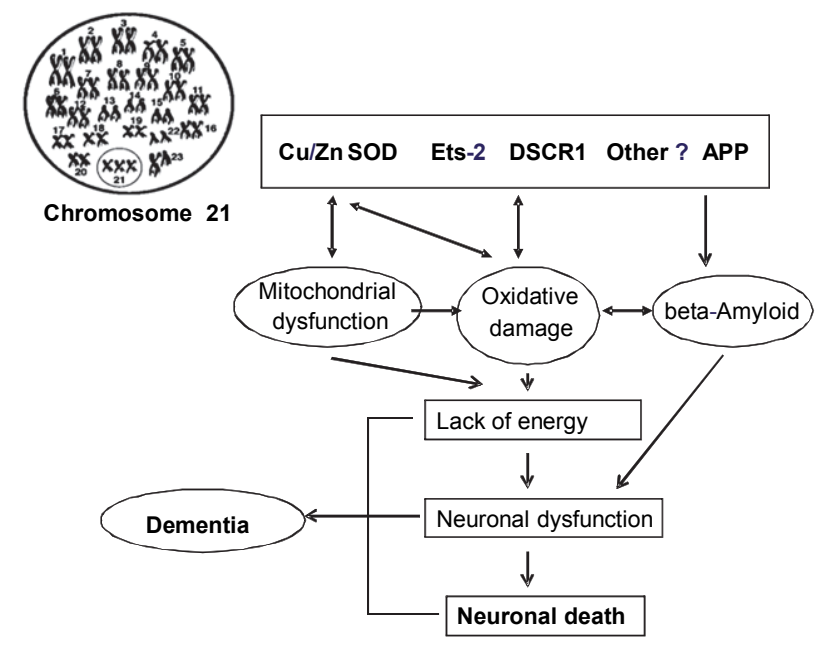

Fig. 3. Down syndrome and aging (adapted according to Lott et al. 2006). Ets-2 - transcription factor, DSCR1 - gene for "Down syndrome critical region", APP - precursor for beta amyloid protein
Mitochondria of the aging cells are characterized by increased production of RM and accumulation of products of oxidative damage to mitochondrial DNA in particular (Pallardó et al. 2010), as well as by dysfunction of mitochondrial respiration and reduction of energy generation (Fig. 3). Increased activity of $\mathrm{Cu} / \mathrm{Zn}$ SOD producing an increased concentration of $\mathrm{H}_{2} \mathrm{O}_{2}$ contributes also to mitochondrial dysfunction which leads to the damage to mitochondrial membrane, damage to mitochondrial pores for passage of $\mathrm{Ca}^{2+}$ ions and to the respiratory chain dysfunction and reduction of energy. Triplet gene for Ets-2 transcription factor located on trisomic chromosome 21 modulates signaling pathways increasing apoptosis of nerve cells. Increased gene dosage of another trisomic gene DSCR1 (Down syndrome critical region) produces a protein that inhibits the phosphatase calcineurin participating in several signaling pathways. DSCR1 is increased in the brain of individuals with DS and it is assumed that it affects the DS phenotype and also inhibits the function of mitochondria (Chang and Min 2005). On trisomic chromosome 21 there is also located a gene for APP/A beta - a precursor of $\beta$-amyloid protein gives rise to $\beta$ amyloid from which $\beta$-amyloid sheets and neurofibrillary tangles are formed. These processes are the basis of pathophysiology of Alzheimer disease (AD) that occurs in DS individuals at an earlier age in comparison to healthy people (Lott et al. 2006). Since the function of mitochondria is associated with oxygen metabolism and also with the formation of superoxide on the one hand, and on the other hand disorder in mitochondrial functions is reflected in the redox imbalance resulting in the oxidative stress (Pagano and Castello 2012).

Effects of antioxidants on oxidative brain damage have been investigated in several studies on canine animal model of aging. It was found that after 1 and 6 months of administration of D,L- $\alpha$-tocopherol, carnitine, D,L- $\alpha$-lipoic acid, ascorbic acid and other dietary antioxidants ability of spatial attention was improved (Cotman et al. 2002). In earlier studies examining effects of antioxidant elements on DS pathophysiology, controversial results were obtained. Zinc $(25-59 \mathrm{mg} / \mathrm{day})$ administered for 6 months had no effect on lymphocyte functions, but daily cough subsided (Lockitch et al. 1989). Selenium $(10 \mu \mathrm{g} / \mathrm{kg} /$ day $)$ administered for 6 months increased levels of $\operatorname{IgG}$ and decreased infections (Annerén et al. 1990) and a dose of $25 \mu \mathrm{g} / \mathrm{kg} /$ day administered for 0.3 to 1.5 years increased activity of GPx and reduced SOD/GPx ratio. 
Supplementation with megavitamin mixtures together with minerals had no significant effect, on the contrary, such megavitamins administration is not currently recommended. Lott et al. (2011) daily administered $\alpha$ tocopherol (900 IU), ascorbic acid (200 mg) and $\alpha$-lipoic acid $(600 \mathrm{mg})$ to 53 individuals with $\mathrm{DS}$ and $\mathrm{AD}$ (Alzheimer disease) for two years. The authors found no impact of antioxidants on cognitive functions compared to the placebo group (Lott 2012). Similar results were obtained in a study with 156 DS children who were supplemented with antioxidants, including reduced form of folic acid (Ellis et al. 2008). At present, reasons of the relative failure of antioxidant interventions is not known, despite undoubted evidence of the presence of oxidative stress in individuals with DS. Whether it is an inappropriate choice of antioxidants, inadequate dose or duration of administration remains under investigation. Promising results were observed when oxidative stress in people with $\mathrm{AD}$ was affected by physical exercise as well as in experimental animal model with a positive impact on learning and memory and on reduction of markers of lipid peroxidation (Berchtold et al. 2010, Littbrand et al. 2011, Zambrano et al. 2009). These results confirm an important role of physical exercise in the function of "physical antioxidant" (Ďuračková 2010) with potential widespread use in children and adults with DS (Andriolo et al. 2011).

Another promising antioxidant for reduction of oxidative stress in DS individuals seems to be the coenzyme $\mathbf{Q}_{10}$ (CoQ) (mitochondrial nutrient), even though it showed no significant clinical results when administered alone (beside inhibition of statin-induced myopathy) (Caso et al. 2007). Tiano and Busciglio (2011) investigated effects of CoQ on oxidative DNA damage. They supplemented DS children with CoQ ( $4 \mathrm{mg} / \mathrm{kg} /$ day) or placebo for 6 or 20 months and found the effect of age on DNA damage. In the younger age group (5-12 years) $\mathrm{CoQ}$ inhibited oxidative damage to DNA pyrimidines and in the age group of 13-17 years oxidized purines were reduced. CoQ might not act as a primary antioxidant, but it interferes with the modulation of repair systems of the damaged DNA.

Furthermore, CoQ regulates permeability of mitochondrial pores, thereby reducing the negative impact of increased calcium transport into mitochondria (Chaturvedi and Beal 2008, Mancuso et al. 2010). A study finished just recently, reported improved language skills after CoQ administration (Miles 2013, www. clinicaltrials.gov/ct2/show/NCT00891917). Furthermore,
CoQ supplementation reduces energy insufficiency and destabilizes formation of beta-amyloid fibrils (Ono et al. 2005). More perspective appears administration of CoQ with other agents, such as creatine and lipoic acid and other substances (mitochondrial cocktail) (Rodriguez et al. 2007, Palacka et al. 2010, Tarnopolsky 2008).

Recently, there appeared also studies demonstrating the positive effect of natural polyphenolic compounds on cognitive functions. It was found that polyphenols present in green tea modulate activity of kinase DYRK1A (dual-specificity tyrosinephosphorylation regulated kinase $1 \mathrm{~A}$ ). It was found that the most important polyphenol belonging to the catechins group of flavonoids, epigallocatechin-3-gallate (EGCG) is an inhibitor of DYRK1A (Pons-Espinal et al. 2013). DYRK1A gene is located on chromosome 21. It is assumed that the increased expression of the gene for DYRK1A and its increased activity is associated with cognitive deficits in people with Alzheimer disease (AD) and might be associated with learning disability characteristic of individuals with DS (de la Torre and Dierssen 2012). One of pharmacological approaches for treating cognitive deficits is based on these facts. Inhibition of DYRK1A function could alleviate several processes such as neurodegeneration in patients with $\mathrm{AD}$, as well as in DS individuals. Pharmacological use of the most effective DYRK1A inhibitor, alkaloid harmine 1a, has been limited for its significant side effects. However, researchers have focused also on other natural and synthetic substances which act on the principle of DYRK1A inhibition (Smith et al. 2012).

Another potential therapeutic target is the neurotrophic factor BDNF (Brain Derived Neurotrophic Factor), a protein formed in the brain and involved in promoting the growth of neurons, synaptic plasticity and survival of neurons (Klein et al. 2011). Increased gene expression of BDNF protein was achieved after administration of curcumin, lipophilic polyphenol substance able to cross the blood-brain barrier (BBB). Similarly, consumption of green tea containing EGCG increased the levels of BDNF and correlated well with improvement in cognitive functions in several studies in China and Japan (Gomez-Pinilla and Nguyen 2012). Melatonin is pineal indoleamine, a hormone, also known as $N$-acetyl-5-methoxytryptamine found in humans, animals, microbes and plants. In animals and humans, melatonin levels vary during the daily cycle. It is involved in regulating the sleeping and waking cycles. It exhibits strong antioxidant abilities. Melatonin has been 
able to reduce neurodegenerative processes and improve cognitive deficits in various animal models. Corrales et al. (2013) have found that melatonin administration might improve the cognitive abilities of Ts65Dn and also control mice by reducing the age-related degeneration of basal forebrain cholinergic neurons. In human study melatonin was analyzed in serum and tryptophan metabolites in urine of 15 children with DS together with 15 controls. Lower levels of melatonin in serum and urinary kynurenine (metabolite of amino acid tryptophan) were determined in patients with DS, although the level of nocturnal secretion of melatonin was higher (Uberos et al. 2010).

As stated above (,physical antioxidant") physical activity and regular exercise have a positive impact on cognitive functions. Cotman and EngesserCesar (2002) found increased BDNF gene expression in animal experiments depending on increased physical activity during voluntary wheel running. Similarly, in addition to elevated levels of BDNF in animal experiments Cotman and Berchtold (2002) using highdensity oligonucleotide microarray analysis found that exercise mobilizes expression of genes predicting improvement of brain plasticity processes. In 15 young volunteers Ferris et al. (2007) found increased serum BDNF, as well as improved cognitive functions after physical exercise during graded exercise test by determination of $\mathrm{VO}_{2}$ max and ventilatory threshold on a cycle ergometer. These results implicate that regular exercise and physical activity should be prescribed to improve neurological health.

In conclusion, oxidative stress is involved in the pathophysiology of Down syndrome, although defence of the organism against its toxicity is amazing. Controlled supplementation with antioxidants, physical activity and regular exercise could be used to improve the cognitive functions and comprehensively benefit people with DS.

\section{Conflict of Interest}

There is no conflict of interest.

\section{Acknowledgements}

The authors thank Mrs. L. Miková for assistance in processing of references. The paper was partly supported by grant VEGA 01/0703/13.

\section{References}

ANDRIOLO RB, EL DIB RP, RAMOS L, ATALLAH ÁN, DA SILVA EMK: Aerobic exercise training programmes for improving physical and psychosocial health in adults with Down syndrome (Review). John Wiley \& Sons, New York, 2011, pp 1-42. DOI: 10.1002/14651858.CD005176.pub4

ANNERÉN G, MAGNUSSON CG, NORDVALL SL: Increase in serum concentrations of IgG2 and IgG4 by selenium supplementation in children with Down's syndrome. Arch Dis Child 65: 1353-1355, 1990.

BERCHTOLD NC, CASTELLO N, COTMAN CW: Exercise and time-dependent benefits to learning and memory. Neuroscience 167: 588-597, 2010.

CASO G, KELLY P, MCNURLAN MA, LAWSON WE: Effect of coenzyme Q10 on myopathic symptoms in patients treated with statins. Am J Cardiol 99: 1409-1412, 2007.

CHANG KT, MIN KT: Drosophila melanogaster homolog of Down syndrome critical region 1 is critical for mitochondrial function. Nat Neurosci 8: 1577-1585, 2005.

CHATURVEDI RK, BEAL MF: Mitochondrial approaches for neuroprotection. Ann N Y Acad Sci 1147: 395-412, 2008.

CORRALES A, MARTÍNEZ P, GARCÍA S, VIDAL V, GARCÍA E, FLÓREZ J, SANCHEZ-BARCELÓ EJ, MARTÍNEZ-CUÉ C, RUEDA N: Long-term oral administration of melatonin improves spatial learning and memory and protects against cholinergic degeneration in middle-aged Ts65Dn mice, a model of Down syndrome. J Pineal Res 54: 346-358, 2013.

COTMAN CW, BERCHTOLD NC: Exercise: a behavioral intervention to enhance brain health and plasticity. Trends Neurosci 25: 295-301, 2002.

COTMAN CW, ENGESSER-CESAR C: Exercise enhances and protects brain function. Exerc Sport Sci Rev 30: 75-79, 2002.

COTMAN CW, HEAD E, MUGGENBURG BA, ZICKER S, MILGRAM NW: Brain aging in the canine: a diet enriched in antioxidants reduces cognitive dysfunction. Neurobiol Aging 23: 809-818, 2002. 
DE LA TORRE R, DIERSSEN M: Therapeutic approaches in the improvement of cognitive performance in Down syndrome: past, present, and future. Prog Brain Res 197: 1-14, 2012.

ĎURAČKOVÁ Z: Oxidative stress. (in Slovak) In: Diagnosis Down Syndrome. ŠUSTROVÁ M, MIŠOVICOVÁ N, ČERNAY J, BÜCHLER P, ČERVEŇOVÁ O, ĎURAČKOVÁ Z, ALGAYEROVÁ M (eds), Perfekt, Bratislava, 2004, pp 208-212.

ĎURAČKOVÁ Z: Some current insights into oxidative stress. Physiol Res 59: 459-469, 2010.

ELLIS JM, TAN HK, GILBERT RE, MULLER DP, HENLEY W, MOY R, PUMPHREY R, ANI C, DAVIES S, EDWARDS V, GREEN H, SALT A, LOGAN S: Supplementation with antioxidants and folinic acid for children with Down's syndrome: randomised controlled trial. BMJ 336: 594-597, 2008.

FERRIS LT, WILLIAMS JS, SHEN CL: The effect of acute exercise on serum brain-derived neurotrophic factor levels and cognitive function. Med Sci Sports Exerc 39: 728-734, 2007.

GARAIOVÁ I, MUCHOVÁ J, ŠUSTROVÁ M, BLAŽÍČEK P, SIVOŇOVÁ M, KVASNIČKA, P, PUESCHEL S, ĎURAČKOVÁ Z: The relationship between antioxidant systems and some markers of oxidative stress in persons with Down syndrome. Biologia 59: 787-794, 2004.

GOMEZ-PINILLA F, NGUYEN TTJ: Natural mood foods: the actions of polyphenols against psychiatric and cognitive disorders. Nutr Neurosci 15: 127-133, 2012.

KADRABOVÁ J, MADARIC A, SUSTROVÁ M, GINTER E: Changed serum trace element profile in Down's syndrome. Biol Trace Elem Res 54: 201-206, 1996.

KEDZIORA J, BARTOSZ G: Down's syndrome: a pathology involving the lack of balance of reactive oxygen species. Free Radic Biol Med 4: 317-330, 1988.

KLEIN AB, WILLIAMSON R, SANTINI MA, CLEMMENSEN C, ETTRUP A, RIOS M, KNUDSEN GM, AZNAR $\mathrm{S}$ : Blood BDNF concentrations reflect brain-tissue BDNF levels across species. Int $J$ Neuropsychopharmacol 14: 347-353, 2011.

LITTBRAND H, STENVALL M, ROSENDAHL E: Applicability and effects of physical exercise on physical and cognitive functions and activities of daily living among people with dementia: a systematic review. Am J Phys Med Rehabil 90: 495-518, 2011.

LOCKITCH G, PUTERMAN M, GODOLPHIN W, SHEPS S, TINGLE AJ, QUIGLEY G: Infection and immunity in Down syndrome: a trial of long-term low oral doses of zinc. J Pediatr 114: 781-787, 1989.

LOTT IT: Antioxidants in Down syndrome. Biochim Biophys Acta 1822: 657-663, 2012.

LOTT IT, HEAD E, DORAN E, BUSCIGLIO J: Beta-amyloid, oxidative stress and Down syndrome. Curr Alzheimer Res 3: 521-528, 2006.

LOTT IT, DORAN E, NGUYEN VQ, TOURNAY A, HEAD E, GILLEN DL: Down syndrome and dementia: a randomized, controlled trial of antioxidant supplementation. Am J Med Genet A 155A: 1939-1948, 2011.

MANCUSO M, ORSUCCI D, VOLPI L, CALSOLARO V, SICILIANO G: Coenzyme Q10 in neuromuscular and neurodegenerative disorders. Curr Drug Targets 11: 111-121, 2010.

MEGUID NA, KHOLOUSSI NM, AFIFI HH: Evaluation of superoxide dismutase and glutathione peroxidase enzymes and their cofactors in Egyptian children with Down's syndrome. Biol Trace Elem Res 81: 21-28, 2001.

MILES MV: Evaluation of Coenzyme q10 (Liq-nol®) Efficacy in Pediatric Patients With Down Syndrome. ClinicalTrials.gov NCT00891917. http://www.clinicaltrials.gov/ct2/show/NCT00891917?term=Efficacy+in+pediatric + patients\&rank=1

MONTI D, TROIANO L, TROPEA F, GRASSILLI E, COSSARIZZA A, BAROZZI D, PELLONI MC, TAMASSIA MG, BELLOMO G, FRANCESCHI C: Apoptosis-programmed cell death: a role in the aging process? Am J Clin Nutr 55: 1208S-1214S, 1992.

MORAWIEC Z, JANIK K, KOWALSKI M, STETKIEWICZ T, SZAFLIK J, MORAWIEC-BAJDA A, SOBCZUK A, BLASIAK J: DNA damage and repair in children with Down's syndrome. Mutat Res 637: 118-123, 2008.

MUCHOVÁ J, ŠUSTROVÁ M, GARAIOVÁ I, LIPTÁKOVÁ A, BLAŽÍČEK P, KVASNIČKA P, PUESCHEL S, ĎURAČKOVÁ Z: Influence of age on activities of antioxidant enzymes and lipid peroxidation products in erythrocytes and neutrophils of Down syndrome patients. Free Radic Biol Med 31: 499-508, 2001.

MUCHOVÁ J, GARAIOVÁ I, ŠUSTROVÁ M, LIPTÁKOVÁ A, BLAŽÍČEK P, KVASNIČKA P, ĎURAČKOVÁ Z: The redox state of glutathione in erythrocytes of individuals with Down syndrome. Bratisl Lek Listy 108: 70$74,2007$. 
ONO K, HASEGAWA K, NAIKI H, YAMADA M: Preformed beta-amyloid fibrils are destabilized by coenzyme Q10 in vitro. Biochem Biophys Res Commun 330: 111-116, 2005.

PAGANO G, CASTELLO G: Oxidative stress and mitochondrial dysfunction in Down syndrome. In: Neurodegenerative Diseases. SI AHMAD (ed), Landes Bioscience, Austin and Springer Science+Business Media, New York, 2012, pp 291-299.

PALACKA P, KUCHARSKA J, MURIN J, DOSTALOVA K, OKKELOVA A, CIZOVA M, WACZULIKOVA I, MORICOVA S, GVOZDJAKOVA A: Complementary therapy in diabetic patients with chronic complications: a pilot study. Bratisl Lek Listy 111: 205-211, 2010.

PALLARDÓ FV, LLORET A, LEBEL M, D'ISCHIA M, COGGER VC, LE COUTEUR DG, GADALETA MN, CASTELLO G, PAGANO G: Mitochondrial dysfunction in some oxidative stress-related genetic diseases: Ataxia-Telangiectasia, Down Syndrome, Fanconi Anaemia and Werner Syndrome. Biogerontology 11: 401419, 2010.

PONS-ESPINAL M, MARTINEZ DE LAGRAN M, DIERSSEN M: Environmental enrichment rescues DYRK1A activity and hippocampal adult neurogenesis in TgDyrk1 A. Neurobiol Dis 60: 18-31, 2013.

RODRIGUEZ MC, MACDONALD JR, MAHONEY DJ, PARISE G, BEAL MF, TARNOPOLSKY MA: Beneficial effects of creatine, CoQ10, and lipoic acid in mitochondrial disorders. Muscle Nerve 35: 235-242, 2007.

SMITH B, MEDDA F, GOKHALE V, DUNCKLEY T, HULME C: Recent advances in the design, synthesis, and biological evaluation of selective DYRK1A inhibitors: a new avenue for a disease modifying treatment of Alzheimer's? ACS Chem Neurosci 3: 857-872, 2012.

STRYDOM A, DICKINSON MJ, SHENDE S, PRATICO D, WALKER Z: Oxidative stress and cognitive ability in adults with Down syndrome. Prog Neuropsychopharmacol Biol Psychiatry 33: 76-80, 2009.

SUBBA RAO K: Mechanisms of disease: DNA repair defects and neurological disease. Nat Clin Pract Neurol 3: 162$172,2007$.

ŠUSTROVÁ M: Down syndrome at the present time. (in Slovak) Pediatr Prax 4: 202-205, 2007.

ŠUSTROVÁ M, ŠARÍKOVÁ V: Down's syndrome-effect of increased gene expression in chromosome 21 on the function of the immune and nervous system. (in Slovak) Bratisl Lek Listy 98: 221-228, 1997.

ŠUSTROVÁ M, MIŠOVICOVÁ N, ČERNAY J, BÜCHLER P, ČERVEŇOVÁ O, ĎURAČKOVÁ Z, ALGAYEROVÁ M: Diagnosis Down Syndrome. (in Slovak) Perfekt, Bratislava, 2004, 240 p.

TAN YH, TISCHFIELD J, RUDDLE FH: The linkage of genes for the human interferon-induced antiviral protein and indophenol oxidase-B traits to chromosome G-21. J Exp Med 137: 317-330, 1973.

TARNOPOLSKY MA: The mitochondrial cocktail: rationale for combined nutraceutical therapy in mitochondrial cytopathies. Adv Drug Deliv Rev 60: 1561-1567, 2008.

TIANO L, BUSCIGLIO J: Mitochondrial dysfunction and Down's syndrome: is there a role for coenzyme Q(10)? Biofactors 37: 386-392, 2011.

UBEROS J, ROMERO J, MOLINA-CARBALLO A, MUÑOZ-HOYOS A: Melatonin and elimination of kynurenines in children with Down's syndrome. J Pediatr Endocrinol Metab 23: 277-282, 2010.

WEISS V: Psychometric intelligence correlates with interindividual different rates of lipid peroxidation. Biomed Biochim Acta 43: 755-763, 1984.

ZAMBRANO JC, MARQUINA R, SULBARÁN N, RODRÍGUEZ-MALAVER AJ, REYES RA: Aerobic exercise reduced oxidative stress in saliva of persons with Down syndrome. Res Sports Med 17: 195-203, 2009.

ZANA M, SZÉCSÉNYI A, CZIBULA A, BJELIK A, JUHÁSZ A, RIMANÓCZY A, SZABÓ K, VETRÓ A, SZUCS P, VÁRKONYI A, PÁKÁSKI M, BODA K, RASKÓ I, JANKA Z, KÁLMÁN J: Age-dependent oxidative stress-induced DNA damage in Down's lymphocytes. Biochem Biophys Res Commun 345: 726-733, 2006.

ŽITŇANOVÁ I, KORYTÁR P, ARUOMA OI, ŠUSTROVÁ M, GARAIOVÁ I, MUCHOVÁ J, KALNOVIČOVÁ T, PUESCHEL S, ĎURAČKOVÁ Z: Uric acid and allantoin levels in Down syndrome: antioxidant and oxidative stress mechanisms? Clin Chim Acta 341: 139-146, 2004.

ŽITŇANOVÁ I, KORYTÁR P, SOBOTOVÁ H, HORÁKOVÁ L', ŠUSTROVÁ M, PUESCHEL S, ĎURAČKOVÁ Z: Markers of oxidative stress in children with Down syndrome. Clin Chem Lab Med 44: 306-310, 2006. 